\title{
A WORD IN MEMORY AN OUTSTANDING UKRAINIAN HISTORIAN, ACADEMICIAN VOLODYMYR HRABOVETSKY
}

\author{
MYKOLA KUHUTIAK
}

\begin{abstract}
The article deals with the scientific work of a famous Ukrainian historian and source scholar Volodymyr Hrabovetskyi. In the creative heritage of the scientist there is a series of works dedicated to the history of Galicia and Precarpathia, studies on the times of Cossacks, national struggles of liberation. Volodymyr Grabovetskyi joined the scientific paradigm as a researcher of the history of the Opryshky movement, the life and activity of Oleksa Dovbush. On the basis of archival materials and contemporaries' memoirs the scientist wrote the history of many Precarpathian cities and villages. Volodymyr Grabovetskyi is also well-known as a researcher of the church history.
\end{abstract}

Keywords: history, Galicia, Precarpathia, Cossacks, Opryshky, Oleksa Dovbush, church history.

The activity of public persons is, at the same time, the history of the nation to which they belong. The story of Academician Volodymyr Hrabovetsky's life confirms the truth of this statement. His activity is inseparable from the historical destiny of the intelligentsia of Western Ukraine, whose creative freedom was curtailed by the totalitarian regime.

Under all despotic regimes in Ukraine, the whole force of the state machine was directed, first and foremost, against the intelligentsia as the exponent of the national idea. A creative person was on their own, physically and spiritually unprotected against the pressure of official ideology, state control, and terror. The Ukrainian intelligentsia suffered constant ideological, political, and moral oppression.

This was the tragic fate of Ukrainian science (the arts in particular), which was held in chains of the Communist ideology. Under especially close observation was historical science; all that was indigenous, ethnic, national was wiped out of it. In those inhuman conditions of spiritual and political enslavement, in that Babylonian captivity (of which none of the European nation had any adequate idea) a part of the Ukrainian intelligentsia managed to reach European standards in their scientific, national, and cultural work. Volodymyr Hrabovetsky was a prominent figure among the nationally conscious part of the Ukrainian intelligentsia.

A brief sketch of the social life in Western Ukraine in the $20^{\text {th }}$ century will give a better idea of Volodymyr Hrabovetsky's activity; the story of his life and career is interesting and edifying.

Volodymyr Hrabovetsky was born on July 24, 1928 into a family of a poor village weaver Vasyl Hrabovetsky in the village of Pechenizhyn, Kolomyia District. There he went to elementary school; Volodymyr continued his education at the Ukrainian grammar school in Kolomyia, the Small Greek Catholic Seminary in Lviv; and later, at the Secondary School for Working Youth in Vynnyky. 
History was Volodymyr's favourite school subject. His family had a great respect for the national traditions and the historical experience of past generations. His father, a former rifleman of the Ukrainian Galician Army, an active member of the Ukrainian National Democratic Alliance, told the young man about the Cossacks, the Carpathian Opryshky*, the struggle for the independence of Ukraine in 1918-1920; Volodymyr read books on world history, the history of Ukraine and the Hutsul land, the land of his birth. It was crucial in choosing his career. Volodymyr Hrabovetsky became a student of the Faculty of History at Ivan Franko University of Lviv.

At the University, he joined the scientific society at the Department of the History of Ukraine and started his research on the history of the Opryshky movement guided by the famous Oleksa Dovbush. In 1953, Volodymyr Hrabovetsky obtained the position as researcher at the Department of the History of Ukraine, the Institute of Social Sciences of the Academy of Sciences of the Ukrainian SSR in Lviv. The Opryshky movement became the central topic of the scholar's research. At that time, the study of the medieval history, the Cossack period in particular, was unofficially tabooed; so exploring the history of the Opryshky acquired a special social meaning.

At the Institute of Social Sciences in the 1950s-1960s, there was created a new scientific historical school led by Ivan Krypiakevych, an outstanding Ukrainian historian. The names of its representatives are well-known in Ukraine today - Yaroslav Isaievych, Yuriy Slyvka, Volodymyr Baran, Yaroslav Shashkevych, Mykola Kravets, Feodosii Steblii, Volodymyr Hrabovetsky. Under very unfavourable conditions of political repressions and total censorship, in the atmosphere that did not encourage any unbiased research, this generation of scholars had to further the cause championed by the distinguished Ukrainian historiographers Volodymyr Antonovych and Mykhailo Hrushevsky in the second half of the $19^{\text {th }}$-the early $20^{\text {th }}$ century; thus a new generation of the Ukrainian scientifichumanitarian elite was being formed.

For fifteen years Volodymyr Hrabovetsky had been working under the guidance of Academician Ivan Krypiakevych; he proved himself a talented researcher of the history of his land. Having studied numerous archival records in Lviv, Kyiv, Moscow, Kraków, Wrocław, he presented significant scientific findings, which bridged many gaps in Ukrainian historiography. In 1958, Volodymyr Hrabovetsky defended his Candidate Dissertation; and in 1968, his Doctoral Dissertation; he became a well-known researcher in the field of Ukrainian medieval and modern history.

In 1975, Professor Volodymyr Hrabovetsky became a staff member of the Faculty of History at Ivano-Frankivsk State Pedagogical Institute named after Vasyl Stefanyk; in 1990, he was elected Chairperson of the Department of the History of Ukraine. The statehood formation processes in Ukraine, a new social, political, and scientific context stimulated Professor Hrabovetsky's professional activity; he had an opportunity to reveal his talent as a scholar, educator, and public activist.

In 65 years of research work, Volodymyr Hrabovetsky had published about 1.5 thousand scientific and popular scientific papers, including more than one hundred monographs; it was the most significant scientific legacy among the Ukrainian medievalist historians of the second half of the $20^{\text {th }}$ century - the beginning of the $21^{\text {st }}$ century.

The array of Professor Hrabovetsky's research works was impressive; still, the history of Ukraine remained the central issue of his studies. Volodymyr Hrabovetsky published fifty works on the history of Kyivan Rus and Ancient Halych. He was the first Ukrainian historiographer to research into the history of a major Ukrainian and European rebellion under the leadership of Mukha; his monograph Selianske povstannia na Prykarpatti pid provodom Mukhy 1490-1492 rr. (The Peasants' Rebellion Under the Leadership of Mukha in Prykarpattia in 1490-1492) was acclaimed by Ukrainian and foreign historiographers.

Volodymyr Hrabovetsky is also known for his research into the history of the Zaporozhian Cossacks (about sixty scientific and scientific popular papers). He gave his full attention to the period of Bohdan Khmelnytsky (the monograph Zakhidnoukrainski zemli v period narodno-vyzvolnoi viiny 1648-1654 rr. (The Western Ukrainian Lands in the Period of the People's Liberation War of 1648-1654)).

\footnotetext{
* Carpathian Opryshky - Hutsul noble outlaws and freedom-fighters of the late sixteenth - early nineteenth centuries [1].
} 
Still, the major theme of Volodymyr Hrabovetsky's research was the history of the century-long national liberation movement of the Carpathian Opryshky, Oleksa Dovbush in particular. The scholar found more than 350 hitherto unstudied archival documents concerning the Opryshky movement of the $16^{\text {th }}-18^{\text {th }}$ centuries, including 70 documents concerning the activity of Oleksa Dovbush; the latter issue was the focal point of 150 works written by Professor Hrabovetsky, the major ones being the monographs Antyfeodalnyi rukh na Prykarpatti v druhii polovyni XVII - pershii polovyni XVIII stolit (The Antifeudal Movement in Prykarpattia in the Second Half of the $17^{\text {th }}$ - the First Half of the $18^{\text {th }}$ Centuries), Karpatske opryshkivstvo (The Carpathian Opryshky Movement), and Oleksa Dovbush. The publications were remarkable events in Ukrainian historiography. The scientific, national, cultural, and educational significance of these works published in the time of the totalitarian Communist regime can hardly be overestimated. At that time, Oleksa Dovbush and the Oprysky movement were the symbols of the undefeated nation and its fight for freedom; they heightened the people's national awareness. Thus we can regard Volodymyr Hrabovetsky's activity of that period as a phenomenon of the national-cultural movement of the 'Sixtiers' - moral resistance to the regime. The researcher was closely watched by the so-called 'competent bodies', their attempts at his 're-education' were nothing less than blackmail and threats.

Yet Volodymyr Hrabovetsky went on with his work. He researched into the history of Prykarpattia thus continuing the tradition set by Mykhailo Hrushevsky, Ivan Franko, Volodymyr Hnatiuk, Ivan Krypiakevych, Stepan Tomashivsky, who attached great importance to the history of the lands and regions of Ukraine.

Volodymyr Hrabovetsky's books Hutsulshchyna XIII - XIX stolit. Istorychnyi narys (The Hutsul Land of the 13 ${ }^{\text {th }}-19^{\text {th }}$ centuries: A Brief Historical Essay), Narysy istorii Ivano-Frankivska (Brief Essays of the History of Ivano-Frankivsk), Narysy istorii Prykarpattia (Brief Essays of the History of Prykarpattia) (a six-volume publication), Iliustrovana istoriia Prykarpattia (An Illustrated History of Prykarpattia) (a three-volume publication) contributed to the historiography of his native land. According to the researcher, a comprehensive study of the historical legacy of regions has to be the basis for a new conceptual comprehension of the history of Ukraine, its role and place in the past and modern geopolitical space.

Volodymyr Hrabovetsky adopted a new approach in the Ukrainian historical urban studies. His first historical essay in this field was Zvenyhorod (1959), then followed a series of essays - Istoriia Kolomyi (A History of Kolomyia), Istoriia Kalusha (A History of Kalush), Narysy istorii Halycha (Bries Essays of the History of Halych), and others, which later developed into profound monographs. The idea to write a history of the cities, towns, and villages of Prykarpattia belonged to Volodymyr Hrabovetsky.

Academician Volodymyr Hrabovetsky did a lot for the development of Ukrainian regional biographical studies highlighting the life and activity of many national heroes of Ukraine - Mukha, Severyn Nalyvaiko, Hnat and Semen Vysochan, Bohdan Khmelnytsky, Maksym Kryvonis, Danylo Nechay, Oleksa Dovbush, Ivan Kapushchak, Ivan Smytsniuk, Vasyl Baiurak, Ivan Boichuk, and many others.

The scientific legacy of the scholar includes about fifty papers in the fields of specific historical sciences - historiography, archeography, genealogy, heraldry, chronology.

In the early 1990s, Volodymyr Hrabovetsky started organizing scientific conferences. It was important to draw attention to vital issues of national historiography after a long period of suppression and distortion of the facts of Ukrainian history. Thus in 1990, there was held a scientific Conference dedicated to the $500^{\text {th }}$ anniversary of the peasants' rebellion under the leadership of Mukha; in 1991, two scientific Conferences dedicated to the $125^{\text {th }}$ anniversary of the outstanding Ukrainian historian Mykhailo Hrushevsky and the $105^{\text {th }}$ anniversary of Academician Ivan Krypiakevych; in 1995, an interuniversity Conference dedicated to the $150^{\text {th }}$ anniversary of a Ukrainian historian Iuliian Tselevych; in 1999, a scientific Conference dedicated to the $120^{\text {th }}$ anniversary of Stepan Tomashivsky.

Another important aspect of Volodymyr Hrabovetsky's activity was archival and museological work. For fifty years he had been collecting documents and data on the Opryshky history; for instance, he had found over a thousand documents concerning Oleksa Dovbush. The scholar contributed to the 
foundation of the Historical and Memorial Museum of Oleksa Dovbush in Ivano-Frankivsk (1995), which developed into a centre of research and patriotic education.

Professor Hrabovetsky successfully combined research and educational work. He was the originator of a new historical school, an educator of a new generation of Ukrainian scholars; its representatives - Igor Tsependa, Petro Siredzhuk, Volodymyr Pryshliak, Mykola Vehesh, Bohdan Havryliv, Vasyl Pedych, and others - are well-known in Prykarpattia and in Ukraine. I can state that in Prykarpattia every new generation historian learned from Volodymyr Hrabovetsky.

As to the scholar's public activity, since 1966, he was a member of the Ukrainian Association for Protection of Historical and Cultural Monuments. In the 1960s-1970s, Volodymyr Hrabovetsky was the recurrently elected member of the Presidium of the Board and the permanent President of the Section of Historical Monuments. He was Honorary Head of the Ivano-Frankivsk Oblast Branch of the National Union of Ukrainian Regional Ethnographers. The researcher initiated setting up the monument to Oleksa Dovbush in the village of Pechenizhyn, and the obelisks and memorial boards to honour the people's hero and his followers in Ivano-Frankivsk, Kosmach, Yaremche.

The atmosphere of the national and state revival encouraged Volodymyr Hrabovetsky to explore little-known periods in Ukrainian history; his publications highlighted the activity of the forgotten heroes of the national liberation movement, scientists, and artists. The researcher presented his findings to teachers, students, the general public; he had his own radio and TV programmes.

For his long and fruitful scientific and pedagogical work, Volodymyr Hrabovetsky was honoured with many awards. In 1995, he was awarded with the title of 'Honoured Worker of Science and Technology of Ukraine' for his contribution to the national historiography. That same year, the scholar was elected Academician of Higher School Academy of Sciences of Ukraine; between 1998 and 2015, he received the Order of Merit, First, Second, and Third Class. Volodymyr Hrabovetsky was an Honoured Citizen of eight cities, towns, and villages of Prykarpattia.

Volodymyr Hrabovetsky died on December 4, 2015. His works are a significant contribution to Ukrainian historiography; his contribution to regional ethnography is invaluable. The range and diversity of his studies is truly impressive. For 65 years he had been tirelessly working for the benefit of his nation, studying its glorious past, educating a new generation of Ukrainian scholars and students, promoting the spirit of patriotism.

May the memory of Volodymyr Hrabovetsky live forever in our hearts.

Address: Mykola Kuhutiak, Vasyl Stefanyk Precarpathian National University, 57, Shevchenko Str., IvanoFrankivsk, 76025, Ukraine.

E-mail: decanat_istor@pu.if.ua.

Received: 07.07.2017; revised: 15.09.2017.

Кугутяк Микола. Слово про видатного українського історика, академіка Володимира Грабовецького. Журнал Прикарпатського університету імені Василя Стефаника, 4 (2) (2017), 41-44.

У статті йдеться про наукову діяльність відомого українського історика і джерелознавця Володимира Грабовецького. У творчому доробку вченого серія праць, присвячених історії Гадичини і Прикарпаття, розвідки про часи козаччини, національно-визвольних змагань. Володимир Грабовецький увійшов у наукову парадигму як дослідник історії опришківського руху, життя і діяльності Олекси Довбуша. Учений на основі архівних матеріалів і спогадів сучасників написав історію багатьох міст і сіл Прикарпаття. Відомий Володимир Грабовецький і як дослідник історії церкви.

Кдючові слова: історія, Галичина, Прикарпаття, козаччина, опришки, Олекса Довбуш, історія церкви. 